\author{
Aleksandra Budrewicz \\ Wydział Filologiczny \\ Uniwersytet Pedagogiczny w Krakowie \\ e-mail: albudrewicz@gmail.com
}

\title{
,Tilly" czy „Miss Slowboy"? \\ Idiolekt jako problem translatologiczny \\ (na przykładzie The Cricket on the Hearth Dickensa \\ w serii polskich przekładów)
}

The Cricket on the Hearth: A Fairy Tale of Home był trzecim opowiadaniem gwiazdkowym Charlesa Dickensa (1845). Zanim powstało, autor miał w planach wydawanie nowego pisma o tytule "The Cricket". Tytuł wybrał nieprzypadkowo: "It is a name and aim which people would readily and pleasantly connect with me" [...] ",a cheerful creature that chirrups on the hearth", zwierzył się przyjacielowi, swojemu późniejszemu biografowi, Johnowi Forsterowi ${ }^{1}$. W założeniu pismo miało spełniać rolę towarzysza czytelników w ich codziennych obowiązkach, miało też kultywować wartości rodzinne, ciepło domowe; zamierzano także drukować w nim recenzje książek i sztuk teatralnych. Pozostało jednak tylko w planach. Dickens otrzymał ofertę od swoich wydawców (Bradbury and Evans), którzy zaproponowali mu objęcie redakcji nowego dziennika „The Daily News", liberalnego w treści i nawołującego do reform. Popularność pisarza byłaby niewątpliwym atutem dla wydawców i potencjalnych czytelników. Dla samego Dickensa taka praca wiązałaby się z koniecznością poświęcenia sporej ilości czasu; byłaby jednak przy tym atrakcyjna finansowo.

\footnotetext{
1 „To jest nazwa i zamierzenie, które ludzie chętnie i przyjaźnie ze mną połączą [...] pogodne stworzonko, które ćwierka za kominem" [M. Slater, Charles Dickens. A Life Defined by Writing, New Haven, London 2009, s. 235 - tłum. własne].
} 
Pismo „The Cricket” wprawdzie nie powstało, ale sam pomysł był jednak na tyle interesujący, że Dickens postanowił wykorzystać go w innej, bardziej literackiej formie. Świerszcz stał się dla niego małym bożkiem rodzinnego ogniska $^{2}$ oraz tytułowym i symbolicznym bohaterem opowiadania. Według Ireny Dobrzyckiej, The Cricket on the Hearth to „hymn pochwalny na cześć cnót domowych i szczęścia rodzinnego prostych ludzi, mniej niż poprzednie opowiadania związany z problemami społecznymi"3. W przeróbce teatralnej okazał się sukcesem na scenach światowych, $\mathrm{w}$ tym polskich ${ }^{4}$. The Cricket on the Hearth ${ }^{5}$ opowiada historię Johna i Dot Peerybingle'ów. Przez niefortunny zbieg okoliczności John (niesłusznie) podejrzewa żonę o zdradę $z$ tajemniczym i nieznajomym przybyszem. Ten okazuje się zaginionym od lat Edwardem, narzeczonym przyjaciółki Dot, May. Razem z małżeństwem Peerybingle'ów mieszka Tilly, opiekunka ich małego dziecka. Drugi wątek opowiadania dotyczy Tackletona, osoby nieczułej i złej, a także Kaleba i jego niewidomej córki Berthy. Tackleton stara się poślubić May, ale dziewczyna wychodzi za mąż za Edwarda. W finale opowiadania, następuje przemiana Tackletona w człowieka dobrego i szczodrego ${ }^{6}$.

Przedmiotem mojej analizy chciałabym uczynić zagadnienie przekładu idiolektu, na przykładzie jednej z bohaterek omawianego opowiadania. Jednostkowe użycie mowy było wielokrotnie rozpatrywane przez językoznawców, literaturoznawców i socjologów. Badanie przekładalności idiolektu czy idiostylu (pojęcie Stanisława Gajdy7) jest z pewnością złożone, o czym prze-

2 "little household god - silent in the wrong and sorrow of the tale, and loud again when all went well and happy" [tamże, s. 236].

3 I. Dobrzycka, Karol Dickens, Warszawa 1972, s. 112.

4 O teatralnej recepcji Świerszcza za kominem piszę w artykule Angielski świerszcz za polskim kominem. O polskiej recepcji The Cricket on the Hearth (do 1939 r.), w: Karol Dickens - refleksje, red. E. Kujawska-Lis i A. Kwiatkowska, Olsztyn 2014, s. 106-121.

5 P. Schlicke, "The Cricket on the Hearth", w: Oxford Reader's Companion to Dickens, ed. P. Schlicke, Oxford 2000, s. 128-129.

6 Podobnego zabiegu fabularnego Dickens użył w swojej pierwszej i najpopularniejszej gwiazdkowej opowieści A Christmas Carol (1843), w której skąpy i nieczuły Scrooge pod wpływem realistycznych i fantastycznych wydarzeń nocy wigilijnej staje się dobrym człowiekiem: ,"[h]e became as good a friend, as good a master, and as good as man, as the good old city knew, or any other good old city town, or borough, in the good old world" [Ch. Dickens, A Christmas Carol, w: tegoż, The Christmas Books, London 1994, s. 76].

7 S. Gajda, O pojęciu idiostylu, w: Język osobniczy jako przedmiot badań lingwistycznych, red. J. Brzeziński, Zielona Góra 1988, s. 23-34. Autor pisze o idiostylu jako stylu indywidualnym, czyli osobniczym; postrzega go jako wydzieloną typologicznie odmianę stylu, odniesioną do tekstów jednego autora [s. 26], a także "złożoną dynamiczną i otwartą całość obejmującą wiele względnie niezależnych subidiostylów" [s. 33]. 
konują studia nad tym problemem ${ }^{8}$. Anna Pieczyńska-Sulik wskazuje na konieczność włączenia idiolektu $\mathrm{w}$ obręb badań nad przekładem, między innymi ze względu na dotychczasowe marginalizowanie w nauce problemów z idiolektem związanych. Badaczka podkreśla wielopłaszczyznowość pojęcia, które zawiera w sobie zarówno kwestię idiolektu autora tekstu wyjściowego, idiolektów poszczególnych bohaterów utworu, jak i samego dzieła literackiego ${ }^{9}$. Rezultatem takiej optyki będzie polifonia idiolektów, jaka dokonuje się w przekładzie: idiolekty bohatera, autora i tłumacza, o czym pisała Joanna Szerszunowicz ${ }^{10}$. Jak wygląda idiolektalny obraz świata bohaterki The Cricket on the Hearth, widzianej i przedstawianej oczyma polskich tłumaczy?

W opowiadaniu Dickensa Tackleton dowiaduje się, że jego narzeczona wyszła za mąż za Edwarda, wyciąga z kieszeni pierścionek owinięty w bibułkę i mówi do Tilly: „Miss Slowboy”, said Tackleton. „Will you have the kindness to throw that in the fire? Thank'ee"11.

Wydaje się, że najprostszą decyzją tłumacza tej wypowiedzi byłoby skopiowanie nazwiska "Slowboy". Każda zmiana przy tak prostej antroponimii literackiej może dziwić: po co zmieniać coś, co zmiany nie wymaga? Jeśli tłumacze rezygnują z podkreślenia, że "Slow-boy" jako nazwisko dziewczyny jest żartem pisarza, bo wprowadza kontrast z jej płcią biologiczną i ciągłą ruchliwością, to forma zastępcza nie jest potrzebna. A jednak polskie przekłady The Cricket on the Hearth ${ }^{12}$ wprowadzają $\mathrm{w}$ tej kwestii odstępstwa od oryginału:

8 Zob. w tej kwestii np. A. Pieczyńska-Sulik, O przydatności kategorii idiolektu w przykładzie na materiale „Wróżb kumaka” Güntera Grassa, w: Recepcja. Transfer. Przekład, t. 3, red. J. Koźbiał, Warszawa 2004, s. 103-115; A. Adamowicz-Pośpiech, Pidgin English and Sailors' Jargon in Polish Translations of Joseph Conrad's "Typhoon", "Yearbook of Conrad Studies (Poland)" 2012, vol. 7, s. 85-96.

9 A. Pieczyńska-Sulik, Przekład - idiolekt - idiokultura, w: Przekład. Język. Kultura, red. R. Lewicki, Lublin 2002, s. 55, 57.

10 J. Szerszunowicz, O elementach idiolektu $w$ przekładzie, w: Idiolekty w różnych sferach komunikacji, red. A. Żurek, Wrocław 2011, s. 74, 84.

${ }_{11}$ Ch. Dickens, The Cricket on the Hearth, w: tegoż, The Christmas Books, London 1994, s. $155-234$.

12 Poniżej zamieszczam listę polskich przekładów The Cricket on the Hearth w porządku chronologicznym, podając skrót, którym sygnuję użyte w artykule cytaty (cyfra wskazuje numer strony; wyróżnienia typograficzne - A. B.):

- K. Dickens, Wybór dzieł, tłumaczone lub przerobione pod red. A. Mazanowskiego, t. 1, Świerszcz za kominem, Poznań 1914 (A).

- K. Dickens, Świerszcz u ogniska, przeł. M. Feldmanowa, Kraków 1923 (B).

- K. Dickens, Opowieści wigilijne, t. 1, przeł. M. Feldmanowa, w: tegoż, Dzieła, red. W. Horzyca, wstęp A. Tretiak, Warszawa 1928 (B1).

- K. Dickens, Świerszcz za kominem, spolszczyła M. Kreczowska [Feldmanowa], Kraków 1946 (B2). 
- Panno Tilly - rzekł do niańki. - Czy będziesz łaskawa rzucić to w ogień? Uprzejmie dziękuję [A, s. 134].

- Panno Tilly - zwrócił się do piastunki - będzie panienka tak dobra wrzucić to do pieca? Dziękuję [B2, s. 118; B3, 148].

- Panno Slowboy - ozwał się - czy zechcesz to łaskawie wrzucić do ognia? Dziękuję [C, s. 137].

Antoni Mazanowski i Maria Feldmanowa-Kreczowska zamieniają nazwisko bohaterki na imię, przez co zdradzają się ze swoimi sympatiami wobec wybranych postaci literackich. W konsekwencji czytelnik tych dwóch przekładów nabiera wobec Tilly Slowboy stosunku bezpośredniego, koleżeńskiego lub opiekuńczego. Krystyna Tarnowska postępuje inaczej. Forma „Panno Slowboy" jest w porównaniu z „Panno Tilly” bardziej oficjalna. W "gramatyce grzeczności" przy używaniu form adresatywnych w języku polskim forma "panno + nazwisko" oznacza wysoki stopień honoryfikatywności ${ }^{13}$. Wypowiedź Tackletona w przekładzie Tarnowskiej odznacza się wyszukaną uprzejmością oraz niecodziennym stylem (rzadka forma historyczna „ozwał się" zamiast współczesnej „odezwał się"). Ceremonialność, uprzejmość i grzeczność Tackletona dziwią czytelnika. Dotąd bohater ten był gburem, lekceważył ludzi i zwracał się do nich z pogardą (wobec Berthy używał określeń „idiotka”, uważał ją za „wariatkę”; panią Peerybingle nazwał „małą grymaśnicą"). O poziomie umysłu Tilly nie miał dobrego zdania. Wobec tego grzecznościowa i oficjalna forma, w której arogancki właściciel firmy "Gruff i Tackleton" zwraca się do sieroty z przytułku, jest niespodzianką. Dlaczego Tackleton wyróżnił osobę stojącą najniżej w hierarchii społecznej bohaterów The Cricket on the Hearth, skoro dotąd był dla wszystkich bardzo nieuprzejmy?

Pozycja Tilly w grupie społecznej, którą opisał Dickens, jest najniższa. W modelu zdarzeń fabularnych odpowiada miejscu niemowlęcia (dziecka Johna i Dott) oraz psa Boxera. Postaci te istnieją jako byty materialne w czasie

- K. Dickens, Świerszcz za kominem, przeł. M. Feldmanowa-Kreczowska, Warszawa 1954 (B3).

- K. Dickens, Świerszcz za kominem: Bajka o domowym ognisku, przeł. K. Tarnowska, Wrocław 1988 (C).

Przekłady M. Feldmanowej-Kreczowskiej oznaczone jako (B), (B1) i (B2) różnią się w stopniu niewielkim, czasem tylko adiustacyjnym (jeśli różnice mają znaczenie dla interpretacji utworu, starano się to zaznaczyć). Przekład B3 był przeznaczony dla szkół i chyba z tego powodu występują w nim poważne zmiany w stosunku do wersji wcześniejszych. Dlatego też uwzględniam go na prawach osobnego wydania.

13 Pojęcie honoryfikatywności przyjmuję za: R. Huszcza, Honoryfikatywność: gramatyka, pragmatyka, typologia, Warszawa 1996. 
i przestrzeni, ale na tok akcji nie mają wpływu. Należą do tła lub scenografii i reprezentują elementy życia codziennego angielskiej rodziny. Zwrócenie uwagi na te epizodyczne postacie pełni w opowiadaniu Dickensa funkcję retardacyjną, umożliwia przegrupowanie osób na scenie powieściowej ${ }^{14}$ i - co najważniejsze - wprowadza do utworu żywiołowość, element chaosu oraz komizm. Tilly prawie się nie odzywa, nie wchodzi z nikim w wymianę replik dialogowych. Interpretacje utworu nie poświęcają jej uwagi. A jednak właśnie idiolekt Tilly jest osobliwy. To jej ruchom i sposobowi mówienia Dickens poświęca najwięcej uwagi. Mikroteksty utworu, które odnoszą się do idiolektu Miss Slowboy, zawierają tak wiele powtórzeń, że są dowodem na bardzo starannie przeprowadzoną charakterystykę językową tej postaci. Seria przekładów The Cricket on the Hearth, która umożliwia różne formy lektury równoległej, odsłania rzadko dostrzegane $\mathrm{w}$ analizach cechy utworu.

Tłumaczenie, a zwłaszcza translacja jednego utworu dokonywana przez różnych twórców, może się [...] okazać doskonałym materiałem badawczym. Przeprowadzona na takiej podstawie lingwistyczna analiza porównawcza może zarówno ukazać upodobania stylistyczne poetów-tłumaczy w zakresie danego tekstu, jak i dać wyobrażenie o ich warsztacie poetyckim, o pewnych charakterystycznych cechach idiostylu ${ }^{15}$.

Sąd Doroty Szagun jest niewątpliwie słuszną dyrektywą ogólną ${ }^{16}$. W praktyce tłumacz zawsze aplikuje do tekstu przekładu subiektywne upodobania estetyczne i cechy indywidualne języka. Interpretując kulturę obcą, z konieczności polega na swoich wzorcach kulturowych, czyli - jak pisała Maria Piotrowska - nakłada filtr kultury docelowej na indywidualny

14 Sceniczny ruch postaci w utworach Dickensa ma często genezę teatralną, dzięki czemu właśnie adaptacje sceniczne odsłaniały mistrzowską celowość przemieszczania się i zastygania w bezruchu. W recenzji z wystawienia Klubu Pickwicka podkreślano tę cechę pisarstwa Dickensa jako wyjątkowo ważną: „wprawiając te marionetki ludzkie w kapitalny ruch, stylizując poszczególne sceny i tworząc nieomal choreograficzne figury" [zob. Z teatru, „Rodzina Polska" 1936, nr 11, s. 398, podkr. - A. B.].

15 D. Szagun, Tłumaczenie jako źródło badań nad językiem i stylem twórcy (Brodziński - Ujejski), w: Język i styl twórcy w kręgu badan wspótczesnej humanistyki. Studia o języku i stylu artystycznym. Tom V, red. K. Maćkowiak, C. Piątkowski, współpraca J. Gorzelana, Zielona Góra 2009, s. 297. 16 Metodologiczne sposoby wypełnienia tej dyrektywy podpowiada książka Magdaleny Pietrzak, Językowe środki kreowania postaci w twórczości historycznej Henryka Sienkiewicza, Łódź 2004. Autorka proponuje „wyekscerpowanie słownictwa nazywającego postaci, określającego jej wygląd zewnętrzny (zarówno cechy stałe, jak i determinowane sytuacją, w jakiej znalazła się postać) oraz słownictwa opisującego stany uczuciowe", szczególnie „sposoby wyrażania uczuć nie wprost" [s. 16]. 
filtr percepcyjny ${ }^{17}$. Przekłady utworów odległych w czasie od rzeczywistości współczesnej tłumaczowi są pod względem warsztatowym trudne. Skróty myślowe i aluzje do aktualnych wydarzeń w sferze publicznej, które kiedyś były powszechnie znane, po upływie lat niewiele już mówią rodakom pisarza, a dla odbiorców przekładu są zupełnie nieczytelne. Postacie literackie w obrębie utworu mogą różnić się pod względem etnicznym, socjologicznym i historycznym. Różnice te pisarze eksponują w języku konkretnych postaci. Jednak po upływie stu czy stu pięćdziesięciu lat język kolejnych generacji czytelników zmienił się. Nowi czytelnicy nie umieją zidentyfikować niektórych cech języka danej osoby, gdyż w ich lekturze wskutek dystansu czasowego język utworu nabrał cech ujednoliconego stylu historycznego. Charakterystyka językowa postaci oraz indywidualizacja języka jest wyjątkowo trudnym zadaniem dla tłumaczy Dickensa, który wiele uwagi poświęcał starannemu odróżnianiu cech języka bohaterów swych utworów. Publiczne odczyty pisarza były dla niego ważną częścią życia zawodowego ${ }^{18}$, a w głośnej lekturze swych utworów Dickens wykazywał kunszt aktorski. Było to możliwe dlatego, że wcześniej pisarz kreował bohaterów według reguł teatralnych i każdej postaci przypisał inne sposoby poruszania się oraz mówienia. Polscy krytycy zwracali uwagę na aktorskie umiejętności Dickensa:

Gdy odczytywał Świerszcza za kominem, bywał kolejno wszystkimi bohaterami tej uroczej i naiwnej opowieści wigilijnej. Wcielał się $\mathrm{w}$ lekturze $\mathrm{w}$ gadatliwą i sentymentalną Kropeczkę, w głupowatą Tilly i w oschłego, zimnego, brutalnego kupca Tackletona. Melancholijny i groteskowy Kaleb, dobrodusznie naiwny John, egzaltowana Berta czy nadęta pani Fielding znajdowali w Dickensie równie dobrego odtwórcę, a każda scena, w której mógł zaspokoić wrodzoną sobie potrzebę patetyczności, spotykała się nieodmiennie z rzęsistymi oklaskami słuchaczów ${ }^{19}$.

17 M. Piotrowska, Strategia kompensacji w tłumaczeniu kultury, w: Język trzeciego tysiaclecia III, tom 2: Konteksty przekładowe, red. M. Piotrowska, seria „Język a komunikacja 8", Kraków 2005, s. 403. W tym kontekście por. też uwagi Krzysztofa Hejwowskiego, dotyczące „percepcji inności" w recepcji przekładu [K. Hejwowski, Kognitywno-komunikacyjna teoria przekładu, Warszawa 2004, s. 93-94].

18 Wśród badaczy Dickensa panuje opinia, że intensywność wystąpień, zwłaszcza jego emocjonalne reakcje podczas lektury fragmentów Olivera Twista (scena morderstwa Nancy przez Sike'a) była jedną z przyczyn pogorszenia się stanu zdrowia pisarza [Ph. Collins, Public Readings, w: Oxford Reader's Companion to Dickens, s. 482; zob. też M. Andrews, Charles Dickens and His Performing Selves: Dickens and the Public Readings, Oxford 2006].

19 J. W. Gomulicki, Teatr Dickensa, „Scena i Widownia Warszawska” 1948, nr 1, s. 6. To teatr dostrzegł potencjał artyzmu tkwiący w kreacji Tilly. W łódzkim Teatrze Popularnym wystawiono w roku 1937 Świerszcza ze starannie obmyśloną rolą dziewczyny. „Niespodziankę spra- 
W tekście wyjściowym dziewczyna o nazwisku Tilly Slowboy jest nazywana przez Dickensa przy użyciu czterech form językowych: Tilly Slowboy -9 , Miss Slowboy - 12, Tilly - 19, young lady - 2. Liczba użyć nazwiska Slowboy odpowiada liczbie użyć imienia Tilly (21:19). Użycie nazwiska oznacza wysoki stopień oficjalności w kontakcie językowym. Zastosowanie zaś samego imienia jest znakiem stosunku bezpośredniego i bliskiego oraz sygnalizuje bliską znajomość. Imienia Tilly używa narrator i postacie opowiadania: John -1 , Kaleb -2 , Dot -6 . Inne osoby zwracają się do dziewczyny $\mathrm{z}$ poleceniem lub z pozdrowieniem. Tilly nie odzywa się pierwsza. Wyjątkiem jest jej zaskoczenie, kiedy nie może się dobudzić śpiącego gościa oraz dialog z Dot. To scena z części trzeciej, w której dziewczyna płacze i tworzy akompaniament dla uczucia rozpaczy żony woźnicy: „’Ow if you please don't!' said Tilly [...] 'Ow if you please don't' cried Tilly [...]” [III, 141-142; podkr. - A. B.].

Niska pozycja Tilly w rodzinie Peerybingle i jej młody wiek nie pozwalają dziewczynie inicjować rozmów. Fakt, że ona pierwsza zwróciła się do Dot, może dziwić czytelnika, ponieważ dotychczas to Dot zwracała się do niej, wydając polecenia, które dziewczyna musiała wypełniać. Znak stosunku partnerskiego (Tilly $\rightarrow$ Dot) jest zaskoczeniem i sygnałem, że pozycja Tilly się zmieni. Tak rzeczywiście się dzieje, kiedy Tackleton zwraca się do niej nie z poleceniem, ale z uprzejmą (choć i cyniczną) prośbą, mówiąc: „'Miss Slowboy' said Tackleton. 'Will you have the kindness to throw that in the fire? Thank'ee'” [III, s. 142].

wia p. Skwarska w niemej roli idiotki - służącej Tilly. Jest to rola, która z łatwością może nie być dostrzeżona. A tymczasem p. Skwarska włożyła w odtwarzaną postać tyle ekspresji, naturalności i precyzyjności, że wysunęła się wśród wykonawców na jedno z pierwszych miejsc" [por. G. Was., "Swierszcz za kominem”: Sztuka Karola Dickensa w Teatrze Popularnym, "Głos Poranny" 1937, nr 268, s. 8]. Tilly wyznaczono w tej inscenizacji rolę niemą, a problem idiolektu zastąpił układ ruchów. Jednocześnie kreacja niemej Tilly stworzyła parę z niewidomą Bertą, co eksponuje $\mathrm{w}$ utworze metafizyczne aspekty niemożności poznania świata i zakomunikowania swej wiedzy o świecie. We wcześniejszej inscenizacji Stanisławy Wysockiej rolę Tilly grały dwie aktorki i w odmienny sposób: „Zupełnie zaś już chybioną była gra p. Kopczewskiej $\mathrm{w}$ roli ślepej córki Kaleba, przedramatyzowana i afektowana gra kobiety i daleko [w oryginale niezrozumiale: „daleką"] bliższą intuicji autora i artystycznej prawdy była gra dublującej tę rolę p. Kunickiej, która dała sylwetkę nieśmiałego, dobrego i kochającego dziewczęcia" [zob. St.M., "Świerszcz za kominem" K. Dickensa, "Ilustrowany Kurier Codzienny” 1924, nr 45, s. 6]. Te dwie koncepcje interpretacji roli Tilly wynikają z przyjęcia odmiennych założeń estetycznych: pierwsze ujęcie jest tragiczną konwencją Ibsenowskiej kreacji niewidomego, a druga wynika z konwencji baśniowej jako podstawy interpretacji utworu. Sława Dickensa-aktora na odczytach była głęboko ugruntowana: „Sławny romansopisarz angielski na prawdziwy talent aktorski i doskonale udaje głosy rozmaitych osób, wprowadzonych w dialogi jego romansów" [Wiadomości polityczne. Francja, "Gazeta Polska” 1863, nr 30, s. 3]. 
Na dwanaście użyć „Miss Slowboy" tylko jeden raz fraza ta pojawia się w funkcji adresatywnej. Nikt poza Tackletonem nie użył jej w ten sposób. Tackletona określilibyśmy dziś jako typ męskiego szowinisty, który pogardza kobietami. Można powiedzieć, że nie tylko nie lubi Dot, ale nawet ją obraża, kiedy po raz pierwszy przychodzi do domu Johna i wita się z nim (,John Peerybingle, my service to you"), a do Dot zwraca się ze słowami: „More of my service to you pretty wife" [I, s. 35]. Jednak w jednej ze scen arogant Tackleton wyróżnia właśnie Tilly - osobę najskromniejszą, najmłodszą, najniższą $\mathrm{w}$ hierarchii, a także osobę komiczną w zachowaniu, która nigdy nie dowiodła, że umie samodzielnie myśleć. W aksjologii chrześcijańskiej pokorna Tilly zostaje wywyższona, a pyszny Tackleton poniżony. Zgodnie z Kazaniem na Górze „ubogi duchem” jest błogosławiony [Mat. V, 3; Łk VI, 20-21]. Tilly stała się narzędziem boskim czy tubą, która nagłośniła prawdę: „This unconscious little nurse gave me a broken hint last night, of which I have found the thread" [III, 170]". To wyznanie ma w polskich przekładach następujące wersje:

Kalebie, oto ta mała, głupowata niańka zrobiła wczoraj kilka wzmianek bez sensu, których nić dziś odnaleźć zdołałem [A, s. 141].

Ta oto piastunka, wcale o tym nie wiedząc udzieliła mi wczoraj pewnej wskazówki, której się trzymałem [B2, s. 123].

Ta piastunka w swojej nieświadomości napomknęła wczoraj wieczorem o czymś, czego potem doszedłem po nici [C, s. 143].

Statystykę użycia słownictwa nazywającego Tilly Slowboy przedstawia poniższa tabela:

\begin{tabular}{|l|c|c|c|c|}
\hline \multicolumn{1}{|c|}{ Zwroty } & Dickens & $\begin{array}{c}\text { A } \\
\text { (Antoni } \\
\text { Mazanowski) }\end{array}$ & $\begin{array}{c}\text { B2 } \\
\text { (Maria Feldmano- } \\
\text { wa-Kreczowska) }\end{array}$ & $\begin{array}{c}\text { C } \\
\text { (Krystyna } \\
\text { Tarnowska) }\end{array}$ \\
\hline Tilly Slowboy & 9 & - & - & 12 \\
Miss Slowboy/panna Slowboy & 12 & - & 4 & 15 \\
Panna Tilly & - & 5 & 31 & - \\
Tilly & 19 & 29 & - & 25 \\
Young lady/młoda dama & 2 & 1 & - & - \\
Młoda dziewica & - & 1 & 1 & - \\
Młoda dziewoja & - & - & 36 & 53 \\
\hline \multicolumn{1}{|c|}{ Suma } & 42 & 35 & & \\
\hline
\end{tabular}


Zestawienie pokazuje duże zindywidualizowanie stylu przekładów. Tilly pełni rolę drugorzędną, ale tłumacze mieli problemy z interpretacją jej osobowości i charakterystyki obyczajowej wraz z indywidualnym językiem. Przekłady A oraz B są pod tym względem prawie identyczne. Tylko w tych wersjach pojawia się forma "panna Tilly”. Mazanowski i Feldmanowa reprezentowali generację, która często używała form grzecznościowych żeńskich typu: „panno + imię w formie zdrobniałej”. Polska literatura realistyczna przełomu XIX i XX wieku oraz pierwszych dekad wieku XX często rejestruje takie formy zwracania się do młodych panien - dotyczyło to kontaktów typu „starszy $\rightarrow$ młodszy" oraz relacji między rówieśnikami. Przekład C reprezentuje okres, kiedy język w kontaktach społecznych wyraźnie osłabiał znaki różnic wieku, szacunku i poufałości. Przekłady A i B są podobne nie tylko ze względu na użycia form „panno Tilly”. Łączy je też niepewność tłumaczy $\mathrm{w}$ interpretowaniu kreacji tej postaci. Mazanowski przełożył neutralne znaczeniowo wyrażenie "young lady" jako „młoda dziewica”. To wyrażenie reprezentuje styl historyczny oraz wysoki; było często stosowane przez polskich pisarzy okresu romantyzmu. „Dziewica” oznaczało wtedy „młodą kobietę, pannę, osobę niezamężną" ${ }^{20}$. Słowa tego używano wobec panien o wysokiej pozycji społecznej i często w kontekstach, które zapowiadały małżeństwo (dziewica - panna na wydaniu). Nie stosowano go raczej wobec panien stanu chłopskiego. Wyrażenie "dziewica" wiązało się z oznaką szacunku, czci, powagi. Określenia współczesnego: dziewica - kobieta do chwili pierwszego stosunku płciowego $\mathrm{w}$ literaturze romantyzmu nie stosowano. Jako sierota wychowywana w domu opieki społecznej Tilly była zaprzeczeniem osób dobrze urodzonych, do których stosowano określenie „dziewica”. Przesłanki te prowadzą do wniosku, że słowo "dziewica" użyte wobec dziewczyny wyraża w przekładzie A intencję ironiczną, a w najlepszym razie - humorystyczną. Tilly jest bowiem zaprzeczeniem kreacji romantycznych i dystyngowanych panien $z$ dobrych domów, czekających na odpowiedniego kandydata na męża.

Określenie „dziewoja”, którego użyła Feldmanowa, jest dziś przestarzałe. Charakteryzuje stan niski, jest trywialne, pospolite i zamiast szacunku wyraża odcień aprobaty czy podziwu dla cech fizycznych młodej kobiety. Słowo „dziewoja” wywołuje asocjacje z fizyczną okazałością budowy, zdrowiem i siłą. Żadnej z tych cech Tilly nie posiada. Ma dziesięć lat, jest bardzo szczupła, a jej ubiór to zaprzeczenie dbałości o wygląd zewnętrzny. Feldmanowa też wyraża ironię, z jaką Dickens opisywał Tilly, ale osiąga to w inny

20 Słownik języka polskiego. Tom I. A-G, red. Jan Karłowicz, Adam Kryński i Władysław Niedźwiedzki, Warszawa 1900-1927, s. 653. 
sposób - przez użycie słowa z zasobu dialektów ludowych. Aluzje do stylu romantycznego (styl wysoki) lub do mowy ludu (styl niski) ujawniają intencje tłumaczy: $w$ ich interpretacjach Tilly jest poniżona, niepoważna, śmieszna albo zabawna; traktuje się ją z wyższością. W przekładach A oraz B Tilly wywołuje śmiech i jest obiektem komizmu degradującego.

W powyższych interpretacjach polskich tłumaczy Tilly jest przykładem na to, że wychowankowie domów dla podrzutków nie rozwijają się prawidłowo fizycznie i umysłowo. Tilly na pewno nie jest odpowiedzialną niańką i potrzebuje sporo czasu, aby zaadoptować się do życia w rodzinie. Nieustannie zderza się z przedmiotami; niezręczność dziewczyny podczas przemieszczania się w przestrzeni i jej wyjątkowa ruchliwość mogą być dowodem, że tej przestrzeni nie zna dobrze, gdyż przebywa w niej od niedawna. Lekarz może na podstawie opisu jej zachowań wystawić diagnozę np. sygnalizującą czynnik ADHD. Hipoteza o problemach zdrowotnych komplikuje problem komizmu postaci. Tilly analizowana jako ewentualny opis diagnostyczny przestaje śmieszyć, a zaczyna budzić współczucie i litość.

Dziecko Dot i Johna ma dopiero dwa miesiące. Niańka też niedawno przybyła do domu Peerybingle (towarzyszyła Dot przy chrzcie dziecka). Być może dlatego Tilly jest tak dziwnie i zabawnie ubrana - ma strój, który dostała w domu podrzutków. Dot, zajęta pielęgnowaniem niemowlęcia, nie mogła dotąd kupić niańce nowego ubrania. Komizm postaci zaczyna odsłaniać litość autora.

Jeszcze ciekawsze wnioski płyną z analizy cechy idiolektu Tilly. Jako osoba naiwna i niemądra posługuje się gramatyczną liczbą mnogą zamiast liczby pojedynczej. Tylko ona jedna $\mathrm{w}$ utworze ma problemy z gramatyką. Na podstawie błędów gramatycznych w jej wypowiedziach można wnioskować, że Dickens na przykładzie kreacji Tilly chciał satyrycznie przedstawić niski poziom edukacji $w$ domach podrzutków, ponieważ wychowankowie mają problemy z opanowaniem systemu językowego. Dlaczego jednak ta cecha idiolektu młodziutkiej dziewczyny jest kopiowana przez osoby, które posługują się poprawną gramatyką? Gdyby intencją Dickensa było nagromadzenie efektów komicznych, to obok komizmu postaci łatwo byłoby wzmocnić efekt komizmu języka, stawiając obok siebie wersję niepoprawną (Tilly) i wersję gramatycznie poprawną (John, Tackleton). Dickens jednak chce, aby „paplanina” Tilly była powtórzona przez dwóch dorosłych mężczyzn, którzy są wyraźnie zaniepokojeni sensem zawartym w jej wypowiedziach, bowiem w tym osobliwym kodzie Tilly opowiada o tym, co się rzeczywiście wydarzyło, co zobaczyła i usłyszała. Jej narrację, zakodowaną w gramatycznym pluralis, powtarzają inne postaci. W efekcie powtórzenia/modyfikacji sem komunikacyjny komiczny odsłania inne znaczenie, dalekie 
od komizmu ${ }^{21}$. Tilly mówi do dziecka, które na pewno nic nie rozumie, ale jej zdania powtarzają dorośli mężczyźni. Ci zaś są pod względem epistemologicznym podobni do niemowlęcia. Widzą i słyszą, ale nie dostrzegają i nie rozumieją tego, co ukryte, co jest zakryte maską (kostium Edwarda) albo jest zapisane w duszy (Bertha). To Tilly otwiera im oczy; mała, niemądra, śmieszna Tilly jest niańką dla dziecka oraz dla dorosłych mężczyzn.

Układ mikrotekstów, w których Tilly używa liczby mnogiej, jest skomponowany według zasady stopniowania. Ma trzy segmenty: introdukcja, sugestia, zagadka. Introdukcja jest ważna dla charakterystyki językowej Tilly, ponieważ od niej zależy sposób interpretacji dalszych mikrotekstów oraz zapisany w nich konflikt semantyczny. Wersja Dickensa:

Miss Slowboy, in the mean time, who had a mechanical power of reproducing scraps of currant conversation for the delectation of the Baby, with all the sense struck of them, and all the Nouns changed into the Plural number, enquired aloud of the young creature, Was is Guffs and Tackleton the toymakers then, and Would it call at Pastry-cookes for wedding-cakes, ad Did its mothers know the boxes when its fathers brought them homes; and so on ${ }^{22}$.

Dickens wprowadza główny element idiolektu Tilly dyskretnie. Stosuje mowę zależną, która następuje bezpośrednio po zapowiedzi o błędach gramatycznych. $W$ ten sposób egzemplifikuje sąd narratora i przygotowuje czytelnika na spotkanie $\mathrm{z}$ dziwną gramatyką w ustach samej Tilly. Na etapie introdukcji narrator całkowicie kontroluje ujawnianie się ech idiolektu postaci. Polskie przekłady stosują tu trzy różne strategie.

1. Ogólna zgodność syntaktyczna z oryginałem:

Tymczasem Tilly, która bezmyślnie bez sensu powtarzała zasłyszane urywki rozmowy, byle zabawić dziecko, i przy tym wszystkie rzeczowniki kładła w liczbie mnogiej, głośno zapytywała stworzonko, czy nie jest on (!) Greffem i Tekltonem, fabrykantami zabawek, czy nie zajedzie do cukierników po weselne kołacze, czy jego mamusie poznają koszyczki, gdy jego ojcowie przywiozą je do domu itp. [A, s. 18 $]^{23}$.

\footnotetext{
21 Nawiązuję do spostrzeżeń zawartych w pracach: P. Żywiczyński, Aksjologia konwersacji: aksjologiczne aspekty preferencyjnej form grzecznościowych i języka ciała, w: Antynomie wartości: Problematyka aksjologiczna w językoznawstwie, red. A. Oskierka, Łódź 2007; Humor i karnawalizacja we współczesnej komunikacji językowej, red. J. Mazur, Lublin 2007; M. Wojtak, Komediowe obrazy potoczności - zarys problematyki, w: Przejawy potoczności w tekstach artystycznych, red. J. Brzeziński, Zielona Góra 2007, s. 133-144; J. Woźnicka, Rola par konwersacyjnych w genezie komizmu, „Acta Universitatis Lodziensis. Folia Litteraria Polonica" 2009, t. 12, s. 283-201.

22 Ch. Dickens, The Cricket on the Hearth, s. 168.

23 Podobną wersję tego fragmentu zawiera pierwszy polski przekład opowiadania, drukowany w „Dzienniku Domowym” w roku 1846 (zaledwie rok po ukazaniu się drukiem tekstu
} 
2. Modyfikacja składniowa, wprowadzenie mowy pozornie niezależnej:

Tymczasem panna Slowboy, która posiadała zdolność mechanicznego powtarzania dla rozrywki niemowlęcia strzępów prowadzonej właśnie rozmowy - ogołacając ją przy tym z wszelkiego sensu i zmieniając w rzeczownikach liczbę pojedynczą na mnogą - zapytywała młodą tę istotkę: Czy torty naprawdę należą do Grufffów i Tackletonów, fabrykantów zabawek. Czy niemowlę jeździłoby do cukierników po torty weselne i czy jego matki zawsze poznają pudła, które ojcowie przywożą do domów. I tak dalej [C, s. 24].

3. Zmiana składni przytoczenia, wprowadzenie mowy niezależnej:

Tilly tymczasem, która miała zwyczaj powtarzać bezmyślnie urywki zasłyszanej rozmowy, wierząc, że tym zabawi dziecko, przy czym wszystkie rzeczowniki wymieniała w liczbie mnogiej, paplała:

- A malutkie pieszczotki są też handlarzami zabawek, i pojadą do cukierni, i kupią kołacze weselne, i mamusie je poznają po okrągłych pudełkach - itd. [B 2, s. 19].

U Dickensa i w polskich przekładach partie Tilly, w których dziewczyna używa liczby mnogiej, następują po konwersacji, w której Tilly nie bierze udziału. Wypowiedź dziewczyny powtarza część informacji przez nią zasłyszanych. Semantycznie i kompozycyjnie takie wypowiedzi pełnią funkcje streszczeń, które oddzielają określony mikrotekst konwersacyjny od kolejnych mikrotekstów. Funkcja sumująca i delimitacyjna jest zatarta przy użyciu mowy zależnej, ale bardzo wyraźna przy zastosowaniu mowy niezależnej. Mowa niezależna autonomizuje idiolekt Tilly. Wprowadzenie do narracji opowiadającej cytatu z mowy postaci przerywa tok opowiadania i wprowadza silniejszy kontrast między poprawnym gramatycznie językiem narratora a zdefektowaną mową postaci.

W procesie autonomizacji języka Tilly Feldmanowa i Tarnowska wprowadziły rozwiązania, które powieść połowy XIX wieku stosowała wyjątkowo. Można taki wybór tłumaczek interpretować jako wpływ konwencji powieściowych modernistycznych i późniejszych. Mogły ulegać temu wpływowi nieświadomie albo uznały, że nowe rozwiązania techniki narracyjnej są bliższe konwencjom, które spotyka współczesny czytelnik. Taki wybór niesie

wyjściowego!) pod tytułem Świerszcz na ognisku, ten fragment jest jedyną „wypowiedzią” Tilly. Brzmi następująco: „a matuchny pościelają łóżka dla gości, a włosy siwe zdejmują z głów jak czapeczki, a matuchny się przelękły, kiedy siedziały przy ognisku..." [K. Dickens, Świerszcz na ognisku. Czarodziejska powiastka Karola Dickensa, „Dziennik Domowy” 1846, nr 25, s. 25]. Tekst opowiadania Dickensa został de facto okrojony, całość skrócono i dodano znaczące zmiany (np. May ma na imię Ellen). Tilly znika z fabuły pod koniec opowiadania i nie pojawią się w ogóle w zakończeniu. 
zagrożenie, że poprzez autonomizowanie języka postaci przekład zbyt silnie odbiegnie od tekstu wyjściowego w budowaniu cech idiolektu. Podajmy kilka przykładów: w wersji Feldmanowej-Kreczowskiej „young creature” zamienia się w wyrażenie pieszczotliwe „malutkie pieszczotki” (nadwyżka emocjonalna, sugerowanie, że Tilly kocha dziecko bardziej niż Dot, która aż takich uczuć w języku nie przejawia); w wersji Tarnowskiej pole wyrazowe przy charakterystyce Tilly jest dużo bogatsze niż u Dickensa (czytelnik tego przekładu jest zdezorientowany, bo tłumacz przekonuje go o braku sensu w wypowiedziach, ale te zdania świadczą o dobrej pamięci dziewczyny i dużym zasobie słownictwa...).

Mikrotekst sugestii ma miejsce w scenie dziwnej reakcji żony woźnicy po zbliżeniu się nieznajomego gościa do kominka.

„Did its Mothers make it up a Beds then!" cried Miss Slowboy to the Baby; ", and did its hair grow brown and curly, when its caps was lifted off, and frighten it, a precious Pets, a sitting by the fires!" [...]

„And frighten it a precious Pets, a sitting by the fire. What frightened Dot, I wonder!" mused the Carrier, pacing to and fro $^{24}$.

John powtarza słowa Tilly, zamieniając liczbę mnogą na pojedynczą (fires $\rightarrow$ fire). John $w$ ten sposób symbolicznie wprowadza porządek kosmosu w chaos spostrzeżeń i języka dziewczyny, ale zmiana liczby gramatycznej nie uchroni go od obrazów, które zapowiadają nadchodzące nieszczęście, czyli triumf chaosu. Rytm frazy łączącej Tilly i Johna (jej segmenty podkreśla aliteracja ",and-a-a”) jest symbolicznym odbiciem praw natury, którym człowiek nie może się przeciwstawić. Jednak wypowiedź Johna powtarza nie tylko wersje Tilly, ale także fragment wypowiedzi Tackletona („I wonder where it's gone, and what is was"). Mechaniczny zlepek przypadkowo usłyszanych słów Tilly i Tackletona zawiera mimo wszystko sugestię zła, które naruszy harmonię domowego ogniska. Ktoś bowiem stanął obok Dot siedzącej przy kominku; ktoś zajął miejsce Johna, bo dotąd to John siedział obok Dot przy ogniu. A właśnie ogień jest symbolem szczęścia rodziny; to $\mathrm{w}$ niego patrzy John, kiedy świerszcz pokazuje mu obrazy przyszłych dni szczęścia. I obok ognia, przy żonie Johna, stanął jakiś młody mężczyzna. Słowa narrator: „Oh Dot! Oh mailing Dot!”, wprowadzają do obrazu pogodnej rodziny, zgromadzonej przy ogniu, zapowiedź nieszczęścia.

24 Tamże, s. 179. 
- Oto mamusie poszły słać łóżeczka - zabawiała tymczasem małego Tilly a włoski mu urosną ciemnoblond i kędzierzawe, a gdy zdejmą z niego czapeczki, wszystkie pieszczotki przelękną się, wszystkie, wszystkie, jakie będą siedzieć przy ognisku [...].

- „I wszystkie pieszczotki przelękną się”. Hm, dziwi mnie, co mogło przestraszyć Dot! - mruczał gospodarz chodząc po izbie [A, s. 39].

- Poszły mateczki posłać łóżeczka! - paplała Tilly do dziecka. - A pieszczotki mają włosy ciemne i kędzierzawe, gdy się z główek zdejmie czapeczki. A kochane paniusie przy ogniu były w wielkim strachu! [...]

- A kochane paniusie przy ogniu były w wielkim strachu!... chciałbym jednak wiedzieć, czym się Dot tak przeraziła! [B 2, s. 36].

- No, no, czy to jego mamusie poszły przygotować mu łóżka - zwróciła się panna Slowboy do niemowlęcia. - I czy mu wyrosły na głowach włosy brązowe i kręcone, kiedy zdjął czapeczki? I przestraszyły moje złote maleństwa, siedzące przy kominach? [...]

„I przestraszyły moje złote maleństwa siedzące przy kominach. Ciekawym, co przestraszyło Kropkę" - rozmyślał woźnica, przemierzając krokami izbę [C, s. 43-44].

Między polskimi przekładami są duże różnice. W wersji A tłumacz zmienił gramatyczny czas przeszły na czas przyszły. Cztery następujące po sobie czasowniki w czasie przyszłym (urosną, zdejmą, przelękną się, będą siedzieć) tworzą serię wydarzeń, które jeszcze nie nastąpiły. Nagromadzenie tego rodzaju słów tworzy iluzję obrazów przyszłości i rodzaj profecji. Harmonijnie łączy się ono z sennymi wizjami czy halucynacjami Johna siedzącego przy kominku. John mechanicznie podejmuje - za Tilly - czas przyszły czasownika. Dzieje się tak, jakby Tilly oddziałała językowo na Johna. Odstępstwa od oryginału są w przekładzie Mazanowskiego największe, ale siła sugestii przyszłego lęku, który dotknie wielu osób (rola cztery razy powtórzonego słowa „wszystkie”), jest największa. W przekładach B i C użyto innego sposobu: tłumaczki wybrały konstrukcję składni, która wyraźnie oddziela zwrot do dziecka i zdanie oznajmujące, którego tematem jest zachowanie Dot. Wyodrębniony w ten sposób segment składniowy przestaje być przykładem na to, że Tilly tylko powtarza to, co wcześniej powiedzieli inni. Wypowiedziane przez Tilly zdanie jest jej samodzielną obserwacją. Zostaje powtórzone przez Johna, przez co John i Tilly zamienili się rolami; John stał się dzieckiem, które nie rozumie tego, co się dzieje, a Tilly nagle wydoroślała.

Tarnowska (C) kolejny raz stosuje zabieg mnożenia wyrazów w stosunku do oryginału, przez co Tilly prezentuje się jako osoba o rozwiniętym słownictwie. Dodatkowo tłumaczka zamienia zdania wykrzyknikowe na pytające, jak gdyby oczekiwała, że niemowlę udzieli informacji lub jakby Tilly 
chciała zaakcentować niepełne rozumienie tego, co widziała. Wersja C różni się też od innych w ten sposób, że tylko w niej - jak u Dickensa - używa się nazwy "panna Slowboy”, a narrator unika jednoznacznego sygnału interpretującego intencje Tilly wobec dziecka. Wersja A („zabawiała”) i wersja B („paplała”) mówią o niefrasobliwości Tilly. Wersja C („zwróciła się panna Slowboy do niemowlęcia”) jest najbliższa Dickensowi: „cried Misss Slowboy to Baby".

Pytania zamiast zdań oznajmujących, które tu zastosowano, są ingerencją tłumacza niezgodną z oryginałem. Ale właśnie zastosowanie pytań ma teleologiczny związek ze sceną wewnętrznego niepokoju Johna. Kolejne części utworu są połączone łańcuchem scen ilustrujących psychomachię woźnicy. Każdą poprzedza motyw wypowiedzi Tilly. Wyeksponowanie przez Tarnowską właśnie pytań, czyli otworzenie utworu na oczekiwanie tego, co ma nastąpić, można wyjaśnić konwencją teatrologiczną, która wymaga absolutnej teleologii każdego słowa, ruchu i gestu. Teatralna koncepcja roli Tilly w utworze jest interpretacją, która wyjaśnia zamiar tłumaczki eksponującej autonomię Tilly. Musimy jednak dodać, że Tarnowska nie była konsekwentna w swojej propozycji przedstawienia dziewczyny, gdyż poprzez nadmiar słów komentujących mowę niezależną Tilly osłabiała zakres tej autonomii. Tilly $\mathrm{w}$ takim ujęciu jest jednocześnie niemądrym dzieckiem oraz kimś, kto widzi przyszłość.

W niewielkim fragmencie tekstu idiolektu obserwujemy trzy różne strategie tłumaczenia: A - wprowadza czas przyszły, C - stosuje ciąg pytań i dystans narratora wobec głosu postaci, a B i C wyodrębniają zdanie odnoszące się do Dot. Każda taktyka w różny sposób przygotowuje czytelnika do odbioru partii widzenia przyszłości przez Johna. Cechą łączącą wszystkie przekazy jest fakt, że wizje Johna operują liczbą mnogą: "Dots, Slowboys, Carriers, many forms..." Gramatyczna liczba mnoga w pewien sposób łączy realistyczne obserwacje Tilly ze światem istot fantastycznych.

Struktura trzeciej wypowiedzi dziewczyny różni się od poprzednich tym, że wywołuje działanie zmieniające rzeczywistość. Zacytujmy fragment z końca części drugiej:

Tilly was hushing the Baby; and she crossed and re-crossed Tackleton, a dozen times, repeating drowsily:

„Did the knowledge that it was to be its wifes, then, wring its hearth almost to breaking; and did its fathers deceive it from its cradles but to break its hearts at last!" 25

25 Tamże, s. 207. 
To parafraza słów Kaleba. Użył ich trzy razy: 1) w finale sceny rozmowy Berthy i May; 2) po rozmowie z córką, kiedy się zajął warsztatem; 3) po wyjściu gości. Kaleb obsesyjnie wraca do tej myśli, dokonuje krytyki swego postępowania wobec córki, w efekcie wyznaje, że ją okłamywał i opisywał Tackletona jako osobę szlachetną i dobrą, przez co spowodował, że się zakochała w człowieku złym. Ze względu na układ słów: wife - deceive - break heart oraz ze względu na temat rozmowy o młodych żonach i starych mężach, przytoczone zdanie Tilly może dotyczyć Kaleba, a dodatkowo również Johna. To kolejny przykład na to, że wypowiedzi Tilly mają sens filozoficznych prawd i zapowiadają sceny psychomachii Johna. Tym razem te słowa wywołują psychomachię trzech mężczyzn: Johna, Kaleba i Tackletona. Dotyczą centralnych kategorii filozoficznych - prawdy/kłamstwa oraz szczerości/oszustwa jako podstawy życia rodzinnego. Tilly podsuwa do rozwiązania zagadkę dotyczącą podstawy moralności - czy można żyć w kłamstwie, które wynika ze szlachetnych intencji? Przekłady polskie:

Tilly usypiała dziecko, przechodząc tam i nazad koło Tackltona [!] (!) i powtarzając na pół sennie:

- Czy serca ich gotowe były pęknąć, gdy się przekonali, że to ich żony? Czy ojcowie oszukiwali dzieci od kolebki dlatego tylko, aby w końcu złamać im serce? [A, s. 90]

Tilly usypiała dziecko, powtarzając sennym głosem:

- A teraz tamte mają zostać jego żonkami, a serduszko tak boli, że omal nie pęka z żalu. A ojczulki ją okłamywali od dzieciństwa, aby na koniec złamać jej serduszko! [B2, s. 80]

Tilly, zajęta usypianiem niemowlęcia, przechadzała się obok Tackletona, mamrocząc sennym głosem:

- A kiedy się dowiedziały, że mają zostać ich żonami, serca o mało co im nie pękły. I czy ojcowie po to je zwodzili od kołysek, żeby im w końcu złamać serca? [C, s. 96]

Konsekwencje niewłaściwej decyzji Feldmanowej-Kreczowskiej, która wykreśliła fragment dotyczący ruchu postaci (u Dickensa Tilly przechadza się obok Tackletona, co celowo podkreśla powtórzenie "crossed" i „re-crossed”), są dostrzegalne dopiero w części trzeciej utworu. W wersji B2 Tackleton mówi o Tilly: „wcale o tym nie wiedząc udzieliła mi wczoraj pewnej wskazówki” [B2, s. 123]. Aby mogła to uczynić, potrzebny był kontakt między nim a Tilly. Kontakt miał miejsce właśnie wtedy, kiedy niańka przechadzała się z dzieckiem obok Tackletona, a właśnie tego motywu w przekładzie Feldmanowej zabrakło.

W przekładach Feldmanowej-Kreczowskiej dodatkowo użyto niefortunnego wyrażenia: „wskazówki, której się trzymałem”. Słowo „wskazówka” 
oznacza, że Tilly w sposób zamierzony i świadomy oddziałała na kupca, a on postąpił konsekwentnie i zgodnie $\mathrm{z}$ planem. W takim ujęciu Tilly i Tackleton wykazują poziom racjonalności, który nie wynika logicznie z finałowej sceny części drugiej. Za to poziom słownika w budowaniu idiolektu Tilly jest u Feldmanowej-Kreczowskiej konsekwentny. W cytowanej wyżej wypowiedzi tłumaczka używa form potocznej mowy ludu: „żonka”, "ojczulek”. Te wyrażenia dobrze korespondują z użytymi poprzednio: „kołacze weselne”, „były w wielkim strachu”. Tilly w przekładzie Feldmanowej-Kreczowskiej jest prostą dziewczyną z ludu i mówi językiem ludowym. W tej wersji tłumaczenia idiolekt Tilly wykazuje dodatkowo wysoką frekwencję hipokorystyk. Można to tłumaczyć stylizacją na język folkloru lub indywidualną cechą osobowości dziewczyny, czyli głęboką uczuciowością. W wersji A tłumaczenie wprowadza zakłócenie sensu. Wyrażenie: "gdy się przekonali, że to ich żony" - wywołuje asocjacje z Johnem, a nie z Berthą. Określenie "przekonać się", czyli uzyskać pewność sądu na drodze empirycznej, zdecydowanie koliduje $\mathrm{z}$ obrazem naiwnej i słabo władającej poprawnym językiem Tilly.

Najciekawszego wyboru stylistycznego dokonała Krystyna Tarnowska. Rytmika pierwszego zdania wywołuje efekt śpiewnego zawodzenia lub la$\operatorname{mentu}^{26}$, co nasuwa skojarzenia z językiem folkloru. Fraza „o mało co”

26 Styl lamentu jest widoczny w części trzeciej, kiedy Tilly rozpaczliwie płacze i uspokaja histeryzującą niemal Dot. W interpretacji tej sceny analiza roli teatralnej jest celowa, gdyż Tilly głośno woła, moduluje głos, a także odgrywa rozpacz przy pomocy szeregu gwałtownych gestów. Dickens podkreślił znaczenie elementów fonicznych, stosując repetycje: cały mikrotekst jest zamknięty ramą "Ow”, które jednocześnie dzieli go na dwie części. Regularne powtarzanie "ow" wywołuje meliczny efekt lamentu. Kolejne człony powtarzają słowo „everybody" i mają dodatkowo rym wewnętrzny: "Ow, was has everybody gone and been and done with everybody; making everybody else so wretched!" [Ch. Dickens, The Cricket on the Hearth, s. 220; podkr. - A.B.]. Ten efekt foniczny zachowują tylko niektóre polskie przekłady: „Oj, co się stało ze wszystkimi, że wszyscy się rozeszli, rozjechali, rozbiegli, tyle innym złego wyrządziwszy!” [A, s. 115]; „U-u-u, co też wszyscy wszystkim wzięli i zrobili, że wszyscy są tacy nieszczęśliwi!" [C, s. 12]. W wersji A Tilly stosuje staranne efekty retoryczne, co jest podkreślone kunsztowną konstrukcją zdania (3 czasowniki, po których następuje imiesłów na końcu frazy); używa tu także języka hiperpoprawnego, co kontrastuje z jej niepoprawną gramatyką. Wersja C wprowadza potoczny język („wzięli i zrobili”), który charakteryzuje Tilly jako prostą dziewczynę z ludu. Obie wersje są interpretacjami uproszczonymi, ponieważ Mazanowski opuścił ważną wskazówkę Dickensa, która podpowiada, jak można zagrać ten fragment aktorsko. W oryginale czytamy bowiem: "she looked at the moment uncommonly like Boxer". Oznacza to, że głos Tilly ma przypominać wycie psa i budzić efekt grozy. Retoryka składni temu nie służy. Tarnowska postąpiła odwrotnie, choć może zbyt naturalistycznie przerysowała animalizm Tilly: „zawołała Tilly odrzucając głowę do tyłu i zanosząc się płaczem; aż dziw brał, jak była w tej chwili podobna do Boksera" [C, s. 120]. Feldmanowa-Kreczowska wprowadziła efekty foniczne, które tworzą dysonans stylistyczny. Tilly woła „,- O Boże, o Boże!" i jednocześnie jest „uderzająco podobna do Boksera”. To niefortunne zestawienie odległych biegunów stylu. 
pochodzi z niedbałej pod względem gramatycznym mowy potocznej. „Mało nie pękły" przypomina frazę spotykaną $\mathrm{w}$ baśniach, $\mathrm{np}$. w polskich przekładach baśni braci Grimm („serce by jej pękło z żałości”). Dzięki tym asocjacjom pole leksykalne, którego centrum jest Tilly, łączy język dziewczyny z jej charakterystyką inicjalną, kiedy narrator podpowiada, iż widok obcego przybysza wywołał w jej umyśle obrazy z fantastycznych opowieści.

Ontologiczny status Tilly jest niepewny. Należy do kręgu postaci, które na scenę powieściową wnoszą ruch, co zbliża ją do elfów i do Boxera (czyli nie-ludzi), a oddala od wszystkich innych. Wydaje się więc zawieszona pomiędzy światem dzieci i zwierząt a światem dorosłych. Jest bardzo nieostrożna, ale dziecko pod jej opieką nie ponosi żadnej szkody. Tilly to dziecko, ale przejmuje funkcję osoby dorosłej, kiedy upomina Dot, że jej płacz może wyrządzić krzywdę synkowi. Rola Tilly w akcji utworu polega na obserwowaniu wydarzeń oraz ich komentowaniu; dziewczyna podsumowuje segment zdarzeń i zapowiada to, co nastąpi. Choreografia i partie dialogowe Tilly nasuwają skojarzenie $\mathrm{z}$ rolą chóru $\mathrm{w}$ tragedii greckiej.

Niejednoznaczny jest też status społeczny dziewczyny. Żyje między rodziną Peerybingle i jej przyjaciółmi a domem dla podrzutków. Przybyła tu z innego świata. Jej dziwna gramatyka i brak przynależności do stałej społecznej lokalizacji świadczą o tym, że jest kulturowo obca i może mieć kontakt z zaświatami ${ }^{27}$. Podstawowa cecha "obcego" to właśnie dziwny, odróżniający go od pozostałych osób język. $Z$ innego świata przybył też tajemniczy nieznajomy, który okazuje się uznanym za zmarłego synem Kaleba. Nie tylko świerszcz i elfy tworzą szereg istot fantastycznych. Tilly i Edward również wpływają na odmianę losów i decyzji kilku rodzin, ponieważ też wykazują cechy reprezentantów innego świata. Przy takiej optyce gramatyka dziewczyny i zaskakujące przejawy honoryfikatywności wobec niej nabierają dodatkowego znaczenia, które pogłębia baśniowość opowieści i wyzwala kreatywność reżysersko-aktorską podczas realizacji scenicznych.

Porównanie sposobów budowy idiolektu w serii przekładów pozwoliło dostrzec w utworze Dickensa znaczenie postaci epizodycznych, które najczęściej są pomijane w interpretacjach. Analiza wykazała, że lingwistyczna metoda opisania charakterystyki językowej postaci może być uzupełniona o perspektywę teatralną, dzięki czemu rola postaci na scenie powieściowej jest pełniejsza. Studiując losy teatralnych adaptacji The Cricket on the Hearth przekonujemy się, że elementy baśniowo-teatralne są ważną cechą struktury tego utworu. Nie ograniczają się do świerszcza i elfów. Potencjalna sceniczność

27 P. Kowalski, Obcy, w: Kultura magiczna: Omen, przesąd, znaczenie, Warszawa 2007, s. 361. 
opowiadania Dickensa dotyczy różnych poziomów utworu. To dzięki niej sam Dickens mógł z takim powodzeniem odczytywać publicznie The Cricket... tak, aby każda postać mówiła własnym językiem.

\section{Bibliografia}

Adamowicz-Pośpiech Agnieszka, Pidgin English and Sailors' Jargon in Polish Translations of Joseph Conrad's „Typhoon", „Yearbook of Conrad Studies (Poland)” 2012, vol. 7, s. 85-96.

Andrews Malcolm, Charles Dickens and His Performing Selves: Dickens and the Public Readings, Oxford: Oxford University Press 2006.

Budrewicz Aleksandra, Angielski świerszcz za polskim kominem. O polskiej recepcji „The Cricket on the Hearth" (do 1939 r.), w: Karol Dickens - refleksje, red. E. Kujawska-Lis i A. Kwiatkowska, Olsztyn: Wydawnictwo UWM 2014, s. 106-121.

Collins Philip, Public Readings, w: Oxford Reader's Companion to Dickens, red. Paul Schlicke, Oxford: Oxford University Press 2000.

Dickens Charles, The Cricet on the Hearth, w: tegoż, The Christmas Books, London: Penguin Books 1994, s. 155-234.

Dickens Karol, Opowieści wigilijne, t. 1, przeł. M. Feldmanowa, w: tegoż, Dzieła, red. W. Horzyca, wstęp A. Tretiak, Warszawa 1928.

Dickens Karol, Świerszcz u ogniska, przeł. M. Feldmanowa, Kraków 1923.

Dickens Karol, Świerszcz za kominem, przeł. M. Feldmanowa-Kreczowska, Warszawa: Czytelnik, 1954.

Dickens Karol, Świerszcz za kominem, spolszczyła M. Kreczowska [Feldmanowa], Kraków 1946.

Dickens Karol, Świerszcz za kominem: Bajka o domowym ognisku, przeł. K. Tarnowska, Wrocław: Wydawnictwo Dolnośląskie, 1988.

Dickens Karol, Wybór dziet, tłumaczone lub przerobione pod red. A. Mazanowskiego, t. 1. Świerszcz za kominem, Poznań: Księgarnia św. Wojciecha, 1914.

Dobrzycka Irena, Karol Dickens, Warszawa: PIW, 1972.

G. Was., „Świerszcz za kominem”: Sztuka Karola Dickensa w Teatrze Popularnym, „Głos Poranny" 1937, nr 268, s. 8.

Gajda Stanisław, O pojęciu idiostylu, w: Język osobniczy jako przedmiot badań lingwistycznych, red. J. Brzeziński, Zielona Góra: Uniwersytet Zielonogórski 1988, s. 23-34.

Gomulicki Jan Wiktor, Teatr Dickensa, „Scena i Widownia Warszawska” 1948, nr 1, s. 6.

Hejwowski Krzysztof, Kognitywno-komunikacyjna teoria przekładu, Warszawa: PWN, 2004.

Humor i karnawalizacja we wspótczesnej komunikacji językowej, red. J. Mazur, Lublin: Wydawnictwo UMCS, 2007.

Huszcza Romuald, Honoryfikatywność: gramatyka, pragmatyka, typologia, Warszawa: Wydawnictwo Akademickie Dialog, 1996.

Kowalski Piotr, Kultura magiczna: Omen, przesad, znaczenie, Warszawa: PWN, 2007. 
M. Wojtak, Komediowe obrazy potoczności - zarys problematyki, w: Przejawy potoczności w tekstach artystycznych, red. J. Brzeziński, Zielona Góra: Uniwersytet Zielonogórski 2007, s. 133-144.

Pieczyńska-Sulik Anna, O przydatności kategorii idiolektu w przykładzie na materiale „Wróżb kumaka” Güntera Grassa, „Recepcja. Transfer. Przekład” 2004, t. 3, s. 103-111.

Pieczyńska-Sulik Anna, Przekład - idiolekt - idiokultura, w: Przekład. Język. Kultura, red. R. Lewicki, Lublin: Wydawnictwo UMCS, 2002.

Pietrzak Magdalena, Językowe środki kreowania postaci w twórczości historycznej Henryka Sienkiewicza, Łódź: Wydawnictwo Uniwersytetu Łódzkiego 2004.

Piotrowska Maria, Strategia kompensacji w tłumaczeniu kultury, w: Język trzeciego tysiaclecia III, tom 2: Konteksty przekładowe, red. M. Piotrowska, seria „Język a komunikacja 8", Kraków: Tertium, 2005, s. 397-404.

Schlicke Paul, "The Cricket on the Hearth”, w: Oxford Reader's Companion to Dickens, red. P. Schlicke, Oxford: Oxford University Press 2000, s. 128-129.

Slater Michael, Charles Dickens. A Life Defined by Writing, New Haven, London: Yale University Press 2009.

Słownik języka polskiego. Tom I. A-G, red. J. Karłowicz, A. Kryński i W. Niedźwiedzki, Warszawa 1900-1927.

St. M., „Świerszcz za kominem” K. Dickensa, „Ilustrowany Kurier Codzienny” 1924.

Szagun Dorota, Tłumaczenie jako źródło badań nad językiem i stylem twórcy (Brodziński - Ujejski), w: Język i styl twórcy w kręgu badan wspótczesnej humanistyki. Studia o języku i stylu artystycznym. Tom V, red. K. Maćkowiak, C. Piątkowski, współpraca J. Gorzelana, Zielona Góra: Uniwersytet Zielonogórski 2009, s. 289-297.

Szerszunowicz Joanna, O elementach idiolektu w przekładzie, w: Idiolekty w różnych sferach komunikacji, red. A. Żurek, Wrocław: Wydawnictwo Uniwersytetu Wrocławskiego, 2011, s. 71-87.

Wiadomości polityczne. Francja, "Gazeta Polska” 1863, nr 30, s. 3.

Woźnicka Jolanta, Rola par konwersacyjnych w genezie komizmu, „Acta Universitatis Lodziensis. Folia Litteraria Polonica" 2009, t. 12, s. 283-201.

Z teatru, „Rodzina Polska” 1936, nr 11, s. 398.

Żywiczyński Przemysław, Aksjologia konwersacji: aksjologiczne aspekty preferencyjnej form grzecznościowych i języka ciała, w: Antynomie wartości: Problematyka aksjologiczna w językoznawstwie, red. A. Oskierka, Łódź: AHE 2007, s. 163-170.

\section{"Tilly" or "Miss Slowboy"? \\ Idiolect as a Problem in Translation: The Cricket on the Hearth by Charles Dickens in the Polish Translation Series}

\section{Summary}

The article is devoted to the problem of idiolect in literary translation on the basis of Charles Dickens's Christmas story The Cricket on the Hearth 
(1845) and its six Polish translations. Special attention is given to the character of Tilly Slowboy and the individual features of the language she uses. The article emphasises stylistic and linguistic differences which can be observed in a detailed comparative analysis of Tilly's idiolect in the Polish translation series.

Keywords: translation, idiolect, stylistics, Charles Dickens 